\title{
ALIREZA MASHAYEKHI'S PAINTINGS (THE CONTEMPORARY MUSICIAN) AND INFLUENCES OF HIS MUSICAL WORKS ON THEM
}

\author{
Shila Sheedfar ${ }^{1 *}$, Navid Khalesi ${ }^{2}$ \\ ${ }^{1}$ Mrs., Department of Art Philosophy, Collage of Art and Architecture, Hamedan Art and \\ Architecture branch, Islamic Azad University, Iran, philart73@gmail.com \\ ${ }^{2}$ Mr., Department of Painting, Collage of Art and Architecture, Yazd Art and Architecture Branch, \\ Islamic Azad University, Iran, navidkhalesi053@gmail.com,
}

${ }^{*}$ Corresponding author

\begin{abstract}
There are many differences In the Arts in delivering their message by their particular language. However, at any time, such as the recent times, the arts are not so close together, the Period which is characterized by abstraction and fading the boundary between arts is its special characteristic. Alireza Mashayekhi As an influential musician, by creativity and change the look of the classical music of the 18th century could be established the modern music in Iran.

This study has attempted to investigate the A. Mashayekhi's painting as the artist with the art of painting and music trends, analyze his works, and review the influences of his music on his paintings. The main purpose of this research is extraction, analysis of qualitative and quantitative indicators of paintings and musical works of A. Mashayekhi and comparative study in some of his paintings and music. There is direct relationship between the painting's detachment and abstraction, with his music form, and there are common aspects in his paintings and his music, that is ideas of modernism, are the hypothesis of this study. The method is Comparative Study, through library studies, fieldwork and analysis, and inferences and conclusions are based on cross-sectional method.
\end{abstract}

Keywords: Aalireza Mashayekhi, Musical elements, Paintings on canvas of Alireza mashayekhi

\section{INTRODUCTION}

At the beginning appearance of musical art was discovered through presenting musical instruments on walls, decorative margins and flower-pots and gradually the daily increasing interest to visual performance concluded to discover exclusive methods in order to imitate the music. When the music became as a form of art, romantic thought has played an important role to unite the music and visual arts. One of findings of the twentieth century was the experiences in visual arts that are inclined to musical styles and techniques and current century is a period that in which specialized improvements has provided the new corresponding relations between visual and audio dimensions. One of the most important remarkable and very interesting, visual imitation of poly-phony (multi-sound) especially for artists who were following the separation in art. Imaginary fuge that was advanced by Ciurlions, Kandensky, Kopka, Kelly, Marsden hartley and some others are evidences of this claim. Most of composers of twentieth century also have entrenched their works 
through searching in visual arts. Among studies which have been done in twentieth century, was the study of a composer named "Jean-yves Bosseur" (1998) as very outstanding. Among his studies he has evaluated the presence of the elements of one art in other art such as illustrating music by visual artists. Also, Cintia cristia (cristia, 2020, page 16) in her article has divided fundamental specification in passing from one art to another art into five levels; Emotional level, Material level, Morphological level, Textural level, Conceptual level and has discussed them.

According to his opinion, transferring phenomenon is passage-way of one element, technique or one object from an art to another art, that the result of this transformation causes the interface and a kind of convergence of different artistic communications in one person.

Verifying the biography and analyzing the works of Alireza Mashayekhi the musician who is one of the Iranian modern composer and in an expanded form, he is messenger of modernism in Iranian music and also he has some works in painting on canvas that their outer appearance are initiated from musical thought of this artist and they are engraved in musical signs that could be an outstanding evidence of Iranian art that the brightness of modernity in his works have been reached to convergence in equality and though in form of three artistic broadcasting (music, painting and literature)

\section{DEFINITION OF MODERNISM}

The word "modern" is extracted from origin of Latin word "modo" which means "of today or whatever is current today (to be different from previous epoch). The Latin word "modo" means "fresh and new". "modern" is used in different periods and places, in order to distinct contemporary styles from traditional ones and in principle could not be applied in each domain of life. (Lowrens, 11,1363) and in spite of this situation, this word has been used in so much various meanings, but could recognize two general and different concepts: first, in art area and second from historical or philosophical aspects. Primary presence of this though which was in renaissance, in eighteenth century, started to be formed as a more spread thinking pattern, therefore, so many sources shows that, end of fifteenth century or the beginning of sixteenth century is the starting point of modern era, and some believe that, for the first time modernism has been used in eighteenth century and be used merely for particular tendencies of new epoch, but its meaning is expanded in nineteenth century, unanimity with modern ideas, styles or manifestation included. But in general, about the matter that, when the modern art precisely started and what artistic work, artistic style, artistic movement or even artistic conversation could be the starting point of modern point in periodic succession of art history, there are some disputes among historians and researchers of modern art.

\section{HISTORY OF MODERN PAINTING}

In reality, modern movement in art has been started by definitive perseverance of one French painter (paul cezanne) who looks at the world as a thing (object). The most clear sign that, was the specification of the twentieth century art could be seen in works of "George Soura" (1859-91). George Seurat is follower of "Della francesca" of modern movement. Two descriptive document are written in the field of modern movement in Munsehen, the first was document of Vilhelm voringer entitled separation and unanimity (1908) that, by that time, it was the first turn by which the desire of separation has been admitted as a repeated historical phenomenon, the second intellectuality and art of Kandensky (1912) that for the first time in that period need of (Abstract art as an internal need) opened up and explained as a contemporary phenomenon. From historical aspect, modernity art research is attributed to the works of pioneers such as "Edward Monet"and "paul cezanne".

\section{HISTORY OF MODERN MUSIC}

At the end of seventeenth century up to beginning of twentieth century, general and specific principles were dominant on audio structure of music. The works of Bach, Beethoven and Brahms as much as they are different, they are benefited from common fundamental techniques in order to organize the boss and low sounds around one central sound. But at the beginning of twentieth century in general there was no more unique system dominant on audio structure of all musical works and each musical piece could have its own special audio system (Kimi Yen, 1387, page:597). Concept of the word "modern" in music, more means aesthetics and technique rather than historical scheduling, therefore in twentieth century the musical color became more important than the past. At the beginning of twentieth century, it was the symbiosis period of various musical styles and impressionism was the most important of these styles and modern music was started with experiences of claude achille debussy and Moris ravel as it means coherent, theoretical and definite comprehension.

Erik Satie (1866-1925), claude achille debussy (1862-1918) that, usually recognized as "father of modern music", and Moris Ravel (1875-1937) who were jointly innovators of new harmonic/ tonal alphabet for music, 
that, tried to imitate fade and weaved figures of impressionism painters and Arnold schoenberg (1874-1951) about 1908 by leaving the tonal traditional system, he has created a revolutionary movement in modern music. Briefly the new approaches in music of twentieth century virtually were different in three styles; rhythmic complexity, dealing with dissonance harmony and rejection of traditional tonality from the past traditions.

\section{ARTISTIC ELEMENTS}

Naturally the first unavoidable question in art is artistic elements which are materials that, artistic works are made with them and they are different in various arts. Visual elements are consisting of point, line, plane, volume and texture, they are elements that make three dimensions' phenomenon in space and in artistic expression they are called space density elements. (Nami, 2012, 20) these elements in combination process (composition), in a visual collection, they provide special quality regarding to visual aspect that, it is an effective factor to transfer contents of work to viewers. The most important of these elements are rhythm, balance, proportion and background. Also, form is three dimensions of object, it is real or conceptual. Also, color is one of other elements that, has many benefits to explain artist's mental concepts.

Elements of music are; sound (pitch, dynamic, color) rhythm, melody, harmony, tonality, form and texture that of course "John Cage" who was one of avant-garde composer of twentieth century has added two other components; morphology and place of each sound in audio space to these elements. To modify each one of musical elements (harmony, melody, form, rhythm and timber) is creating a new composition in music.

\section{BIOGRAPHY OF ALIREZA MASHAYEKHI}

Alireza Mashayekhi was born on March, 30, 1939 in Tehran, he has completed his elementary and high school education in Elmieh school in Tehran, and he went to Viena, the capital of Austria to continue his higher level of education in academy of music and performing art, then to continue his academic studies he went to university of Utrischt in Holland (Netherland). Mashayekhi's activities as one of pioneers in contemporary music area is presented in 1350 (1971) decade in Iran. At the end of 1971 decade, he travelled to U.S.A and completed his findings about modern and contemporary arts; finally he returned to Iran in 1990s and established the new music orchestra at the same time. In an interview with Alireza Mashayekhi, to answer this question that "What was happened that, the idea of painting and music contras has been got to your mind?" He explained:

In position of composer it was a long time that, due to composing needs I was busy to design the musical signs and for me it was a part of my composing work.

About 1991, I came to Iran, I traced the canvases and paints and finally I have implemented my first plan. After primary test, I used paint in composition and later I reached to some common working styles that summarized them as follows:

A- When I write a piece of music on canvas and a painter states his comment on it.

B- When a painting canvas is background of my composing.

C- When me and a painter were designing a whole composition together, and we were periodically working on it.

I have never painted. Only in one period of my life I loved to write my music on canvas. Although I do not write music on canvas but my relation with musical graphic continues for the sake of writing music.

\section{ANALYSIS OF WORKS ON CANVAS}

In this research, for verification of visual elements three paintings of Alireza Mashayekhi have been analyzed (one colored work and two white and black works) that, each work one time has been analyzed in general and another time after analyzing to primary visual elements regarding to synchronism, lines, rhythm, based on lines direction, color, musical elements, existent points in picture and semiology according to note writing in Alireza Mashayekhi's work collection distinctly. 

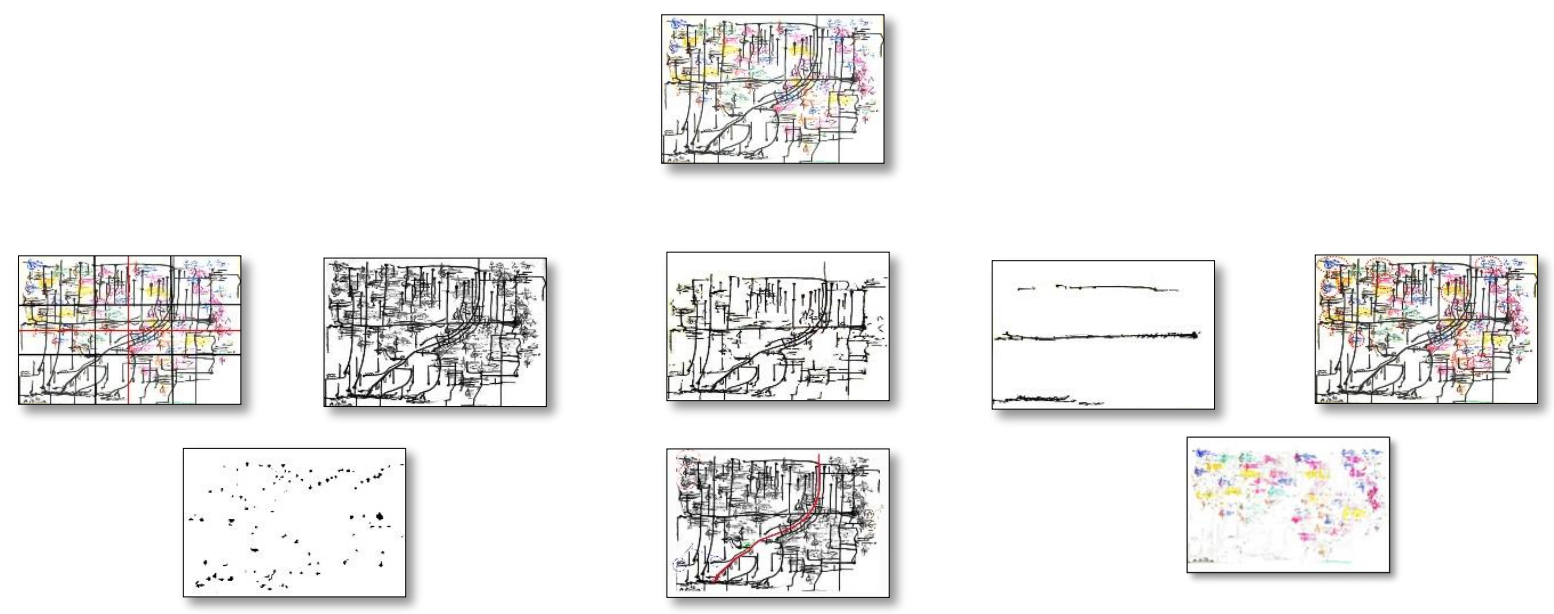

Painting no 1 and images of its analysis
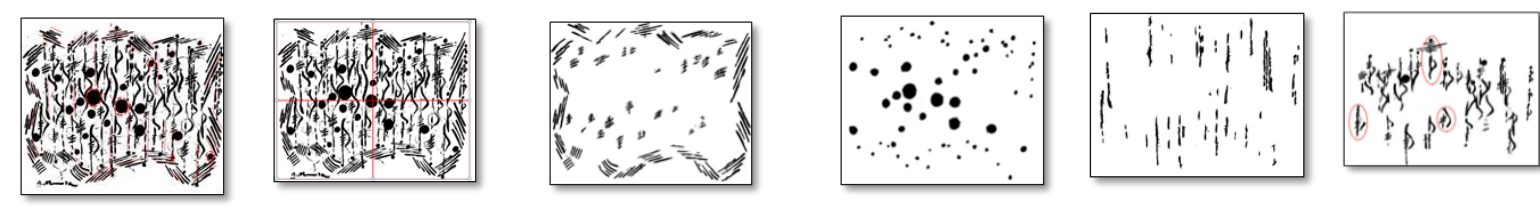

Painting no 2 and images of its analysis
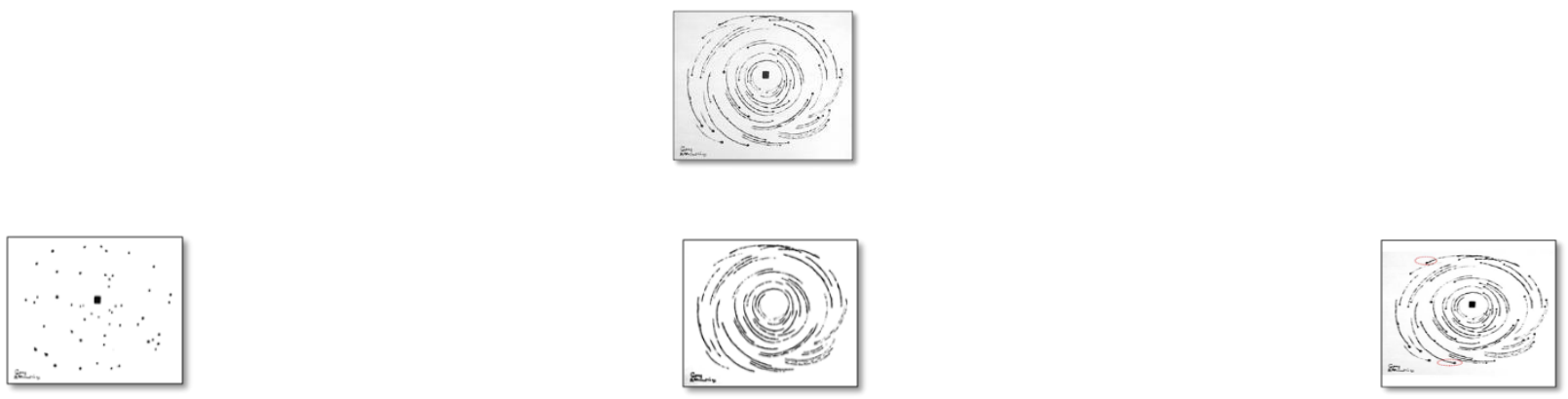

Painting no 3 and images of its analysis 


\section{ANALYSIS OF NEW MUSIC ORCHESTRA AUDIO ALBUM, IRANIAN SYMPHONY, ZAGROSS}

To comprehend the musical pieces of the above-named artist, demanding to know so many introductions that, could not be put in this limited article, but in relation to his music (Iranian Orchestra for new music, Iranian Symphony and Zagross).

We should mention some points:

-In his musical texture of his works we are observing two ranges of texture, from simples to complicated form, that, in some works by deleting musical elements it is simplified and in some other works, based on symphony elements, the form is more complicated.

-In spite of having an element named point, but we could see point as an intensive and heavy element in dynamic, in texture as the sound compactness in some moments and in rhythm with emphasizing by percussion.

-Also, line is not musical element but it could be seen in themes, in form of short and long theme and also it could be seen in orchestration, in theme performing by one musical instrument against performance of several musical instruments.

-Musical texture of three evaluated works of him, especially in during the melodies, it was often homophony rather than polyphony and it has two spectrum from uncrowned to crowded and vice versa. Also, repeating of motives and simplicity in texture are seen.

-Artist's concentration was more on rhythm, rather than be on tone colors, rhythms without intensive contrast, repeatable, free and elongated.

-Regarding to tone color like texture of melodies, we are faced to two ranges which means color in his audio tracks, is changeable from monotone color space with law contrast up to multi- color space with more contrast.

-In composition, variety and movement within dynamic are seen, and in spite of distortion dominant space, the work has balance and also a type of stasis. Free harmonies in vertical texture and dominating of counterpointic (horizontal) comparing to harmonic texture (vertical) are other specifications of these two audio tracks.

\section{DISCUSSION \& VERIFICATION}

Although could not reach to a unique system in fine arts and although music has attractiveness to be comprehended in hearing domain, but could not doubt to musical effects out of its auditory aspects in other artistic areas and Alireza Mashayekhi, Iranian artist has provided symbolic conformity between these two arts in a manner that, he animates whatever he has painted on canvas and it associates movement and dynamism, and this is nothing but only sound or music, and these are the same musical elements which are painted on surface and has sightseeing.

In direction of this research although we studied the effects of musical elements on his paintings, but our purpose for this research was not comparing each element of these two arts, because only some elements like texture, color, composition, rhythm and form in two fields are common of course regarding to definition, and some others like point and line have a precise definition only in painting in music we made merely a type of equivalent because these two elements have no definite and objective definition and they are not counted as main musical elements, but in a composition they have their particular importance.

In direction of main purpose and sub purpose of this research a time-table is prepared (table no.1) and based on mentioned table no.1, the quantitative and qualitative criterions which are the same elements, have been compared, also the common different aspects in the works of the above-named artist with two artistic attitudes in painting and music which were sub-purpose of this research, have been extracted. 
IJASOS- International E-Journal of Advances in Social Sciences, Vol.II, Issue 6, December 2016

Table 1 - comparative Time-table of Visual and Musical Elements

\begin{tabular}{|c|c|c|}
\hline $\begin{array}{l}\text { Visual } \\
\text { elements }\end{array}$ & Analysis of painting & Musical Analysis \\
\hline Form & Simplicity and repeatable forms & $\begin{array}{l}\text { In some works by deleting musical elements } \\
\text { he is doing some kind of simplicity and in } \\
\text { some other works based on symphony } \\
\text { elements the form will be more complicated } \\
\text { (having two ranges from simple to } \\
\text { complicated). }\end{array}$ \\
\hline Point & $\begin{array}{l}\text { Existence of many points shows } \\
\text { and black points (symbolic notes) } \\
\text { explains intensive stroke, regarding } \\
\text { to measure and quantity are against } \\
\text { each other. }\end{array}$ & $\begin{array}{l}\text { Point could be seen in dynamism as an } \\
\text { intensive and heavy element in dynamism, in } \\
\text { texture as the sound compactness in some } \\
\text { moments and in rhythm with emphasizing by } \\
\text { percussion }\end{array}$ \\
\hline Line & $\begin{array}{l}\text { Vertical lines dark in color, broken } \\
\text { lines with right angle, thickness in } \\
\text { drawing, combination of lines that } \\
\text { are different only in length. }\end{array}$ & $\begin{array}{l}\text { Line could be seen in themes as the short and } \\
\text { long themes and also in orchestration, in } \\
\text { theme performance by one musical instrument } \\
\text { against performance of several musical } \\
\text { instruments. }\end{array}$ \\
\hline Texture & $\begin{array}{l}\text { Has an uncrowded texture and only } \\
\text { in some places are filled }\end{array}$ & $\begin{array}{l}\text { In length of melodies, often homophony and } \\
\text { less polyphony, uncrowded to crowded and } \\
\text { vice versa, repeating motives, simplicity in } \\
\text { audio and harmonic context. }\end{array}$ \\
\hline Rhythm & $\begin{array}{l}\text { Often vertical rhythm, rhythms have } \\
\text { more importance, repeating one } \\
\text { moteif. }\end{array}$ & $\begin{array}{l}\text { Concentration on rhythm, without intensive } \\
\text { contrast, repeating the rhythm, free and } \\
\text { longitude (continuous). }\end{array}$ \\
\hline Color & $\begin{array}{l}\text { Colors are in background, variety of } \\
\text { color is little and two black and } \\
\text { white colors are mostly used, } \\
\text { contrast in color (black and white). }\end{array}$ & $\begin{array}{l}\text { From unique tone color space with low } \\
\text { contrast up to multi-color space with more } \\
\text { contrast, is changeable. }\end{array}$ \\
\hline composition & $\begin{array}{l}\text { Harmonic visual relations, painting } \\
\text { margins which is rectangular gives } \\
\text { a type of balance and dynamism in } \\
\text { a work, movement, visual variety } \\
\text { and attraction }\end{array}$ & $\begin{array}{l}\text { Variety and movement joining to dynamism, } \\
\text { existence of balance in crooked type contrast } \\
\text { of space and statistic too, free harmony in } \\
\text { vertical context, counterpointic context is seen } \\
\text { more than harmonic in composition }\end{array}$ \\
\hline
\end{tabular}

\section{CONCLUSION}

Following the research, we will prove the theories of this research and we will answer them one by one.

To answer the first question and to prove the theory which was trying to find relation between musical and painting form in Alireza Mashayekhi's works could say:

From specification of almost comprehensive of modernism which distinguish it from other theories, is type of internal and structural looking to art itself and searching new frame to explain it, therefore we remind painting and music of an artist like Mashayekhi as modern art, because technical matters in his verified works in this research such as form and combination, fundamental elements like color, context, dot and ....has more priority according to the subject, dealing with internal world and attitude to mentalism based on his thinking philosophy and in direction of his thought, being more abstract and get away from traditional structure of story is seen in his works. Also in his music, the tumultus and stroking sound, leaving tonal traditional system themeless composition and without tonality, using compound changed rhythms instead of using patterns and 
accents order shows a modern form.

In order to prove the second theory concerning creative aspects of Mashayekhi's work could mention the breaking of form and avoiding the usual traditions in painting and music, also the different experience which have been gained by integration of Iranian traditional music with western music, according to having interest to Iranian traditional music which is peculiar to this composer, these are creative appearances of his works.

The third question which is related to Alireza Mashayekhi's attitude to traditionalism and modernity in his painting and musical works, this theory has been proved as follow:

When discussion of modern art happens, most of people imagine a type of art which is completely separated from traditions of the past, while if in modern art, getting away from tradition, this does not mean the complete discontinuity may be always elements remained from tradition and changed to form of these days. According to Mashayekhi's opinion, one of obvious facts, that, we are always trying to prove it is "modernism" and necessity to orient ourselves with changeable. Keeping the good factors which we have should not prevent their growth and become better than what they were, and "modernism" shouldn't take them from us. We could interpret "modernism" as "to look better", "to complete" "to look from different angle", "to discover new horizons" and "designing a new solution". Thus "modernism" in art and music changed to a necessity. Mashayekhi has called this type of concerning "new" to the "past" as "looking to the past" and argues that if there is a treasure in the art of the past and some parts are remained to be discovered, and if type of new looking to some moments of past history, satisfies the necessity of "modernism", we are authorized to put the past illustration in the path of future, wherever is necessary and this is not contradiction to "modernism" and even in most of the time, it is "modernism" itself. Based on this idea and emphasizing on necessity of modernism in art and music it seems that, his thought of modernism is common aspect of Alireza Mashayekhi's painting and musical works.

Finally, we should omit that, fact of convergency and converting elements from one art to another art is not only one method but could be performed based on one legendary space calling, and sometimes based on receiving surfaces and converting the abstraction (music as a non-visual art and the most abstractive art) to visual surfaces or vice versa, even sometimes based on physical surfaces, that is the same elements of forming them, this is different in various people and also unique. By looking at paintings of an artist such as Mashayekhi, music of painting and its artistic structure could be heard and at the time of hearing his music, comprehension of its visual structure in abstractive space could be seen and transferring the elements of one artistic medium to another medium by this artist according to his musical and visual works are seen.

\section{REFERENCE LIST}

\section{Books}

Abedini Manesh - Sh, 2009, Note Writing in Mashayekhi's Works Collection, first edition, Tehran- Cheshmeh publication, 81 pages

Abraham- J, 2011, Oxford Music Summarized History, translated by N.Choobineh, second edition,TehranMahoor Cultural -Art Institute, 904 pages

Ahmadi -B. 2010, musicology, eight editions, Tehran- Markaz publication, 517 pages

Asgari -M. 2008, Continuity of Thinking, first edition, Tehran - Cheshmeh publication, 292 pages

Childs -P., 2013, Modernism, translated by R-Rezaei,fourth edition,Tehran- Mahi publication, 268 pages

Dandys -A. Donis, 2011, Visual Knowledge Introduction, translated by M-R-Afzal, first edition, Tehran Yazad publication, 249 pages

Esposobin -E, V, 2010, Form of music, translated by M,Ebrahim, first edition, Tehran -Hamavaz publication,352 pages

Gambrige- A, 2011, History of Art, translated by E- Ramin, seventh edition, Tehran- Ney publication, 674 pages

Golsabahy -G. 2003, Towards East, first edition, Tehran, Talkhoon, 1350 pages

Goudarzi (Dibaj)- M, 2009, Analysis Method of Painting Works, second edition, Tehran -Ataei publication Institute, 167 pages

Grifith -P. 2007 Century Modern Music Translation by K-Mirhadi, second edition, Tehran -Afkar publication, 


\section{8 pages}

Halimi- M, 2012, Principles and Basic of Visual Arts, tenth edition, Tehran- Ehya ketab publication, 319 pages

Hosseini-S 2010, Sohrab Hosseini's Conversation with Alireza Mashayekhi, Musical Position, 127-117:1

Itten -E, 2010, Design and form,translated by P.Sayyar, third edition Tehran- Soroosh publication, 206 pages

Kandensky $-\mathrm{V}$, 2011, Dot, Line,Surface translated by $\mathrm{P}$ - Mohagheghzadeh, fifth edition,Tehran, Marlik publication. 144 pages

Kandensky -V, 2011, Spirituality in Art, translated by A - Noorollah Khani, fifth edition, Tehran -Asrar Danesh publication, 155 pages

Clark -M, 2010, Oxford Art Expression Compacted Dictionary, translated by A.A- Rezaei, first edition, Tehran - Barg Negar publication, 314 pages

Pakbaz- R, 2011 Encyclopedia of Art, eleventh edition, Tehran -Farhang Moaser publication, 1033 pages

Read - H, 2011, History of Modern Painting, translated by Sh. Golbabaei, first edition, TehranFarhangsaraye Mirdashti publication, 348 pages

Sami Azar- E, 2012, Conceptual Revolution, first edition, Tehran- Cultural Research Institute, Nazar publication,276 pages

Solomon -L- J, 2010, Eric Sati, The First Modern Musician, translated by E-Masoudi Nia, Musical Position, 23:2 pages

Sirlout -L. 2012, Modern Art Guide, translated by N- Hashemi, fourth edition, Tehran -Saghi publication, 85 pages

Kamien $-\mathrm{R}, 2008$, Comprehension and understanding of Music, translated by $\mathrm{H}$-Yassini, seventh edition, Tehran -Cheshmeh publication, 983 pages

Lotfi- Sh, 2002, Basic New Methods of Music Performance, first edition, Tehran- publication of Art University, 195 pages

Lotfi- Sh 2013, Musical Thoughts, first edition,Tehran- Dibayeh publication, 119 pages

Linton-N, 2014, Modern Art, translated by E- Ramin, Tehran -Ney publication, third edition, 520 pages

Mayer. M. F, 2012, Visual Art Basis In Baze School- Switzerland, translated by E.E Sharbeh, third edition, Tehran-Sharbeh, third edition, Tehran - Shabahang, publication, 384 pages

Naseri- F, 2013, Music Expression Comprehensive Dictionary, fifth edition, Tehran-Rozaneh publication, 488 pages

Nami- Gh, Visual Art Basic, Visual relations, seventh edition, Tehran -Toos publication, 156 pages

Sheperd -A. 2011, Philosophy Art, translated by E- Ramin, first edition, Tehran - Scientific and Cultural publication co. 307 pages

Sarmad -Z, Bazargan - E, Hejzi -A, 2002, Research methods, in behavioral sciences, Tehran -Agah publication, 250 pages

Turek $-\mathrm{R}$, 2011, Elements of music, translated by E-Seyed Ahmadian, second edition, Tehran-Mahoor Cultural -Art Institute, 528 pages

Turek- R. 2011, Basic Form and Musical Forms translated by M.Elhamian, first edition, Tehran-Part publication, 304 pages

\section{Thesis}

The convergence of music, 2009- Adomo's physiognomical Image of Mahler,I painting and language" ETheses online, Durham university, Durham, UK

\section{Article}

The Musical Quarterly On Some Relationships between 1995-Adorno T W, Gillespie S, 66-79 PP.1 79 Music and Painting "Vol". 


\section{Internet}

Mashayekhi A. 2008. Composition. Available from: [Accessed 7 January 2015]. $\quad$ /en/compositions.htm http://www.alirezamashayekhi.com

Veguri R. 2014. Projects. Available from: http://toermagazine.com/tag/projects[Accessed 7 January 2015]. 